\title{
This April Day
}

\section{Pauline Kennedy}

TheY LEFT without him! Len wanted to be with his unit, but he missed his starting point for The March. He was too late. He walked with two sticks now and there was no chance of catching up.

Len didn't want to be late. Not today. Reluctantly he said to the boys that he couldn't make the Dawn Service this year, and Len always went to the Dawn Service, but he'd definitely be there for The March.

Every year as April drew closer he went to greater lengths to be prepared. He double-checked The March route and his regiment's assembly point. He checked with Jack, Danny and Laurie to confirm their post march drinks at The Royal just like the year before. He never drank there otherwise, his local was The Station before it became gay and funky. Nowadays he had few drinks and he missed his bar, but he wouldn't stray to The Royal, because that was for The March. There was tradition to be observed, mates to toast, memories to acknowledge, pride and grief to release.

He wanted to get his suit dry-cleaned but his wife complained that there was no need, that he was being silly and getting agitated. Why get a brand new suit dry-cleaned when it hadn't been worn? It would be different if it were the antique he wore to his daughter's wedding the previous September. Len kept that suit smart and sharp over the years but even he had to admit defeat when the seat seams frayed a little too far. But, April was different. This April day is a different day to September wedding days and it also requires a suit, so Len got a new one, but he still had it dry-cleaned.

When Len's wife saw the glad-wrapped suit with regimental tie she smiled sadly. She found his black shoes at the back of the wardrobe and took them to the laundry for a quick polish. From the ironing basket she took a freshly pressed handkerchief and placed it inside his left shoe so that he would find it easily in the morning. 
Len found his wife in the laundry with the lid of the nugget tin spinning on the floor. She couldn't replace the lid with her knobbly fingers and it slipped from her grip. He smiled gently at her efforts and admonished her kindly saying she didn't have to polish a soldier's boots. He said she should look after herself, and he bent to give the ugly fingers a kiss. She replied she was proud of her soldier and seeing that she only polishes his shoes once a year, it wouldn't hurt to polish them this year as well. He stretched down to collect the errant lid and awkwardly grunted as he straightened up. Len heard her sigh, the content sigh of 40 years of marriage, and he stiffly righted himself. He replaced the lid and put the shoes in their box. He would not get a veteran's car. He made that quite plain last week and he would not allow her to bring it up again.

His regiment marched on and were halfway around the corner. The Mounted Police blocked his view and the snare drums beat time behind them. The shock of missing his place rose up inside Lens's throat and he tried to swallow. His tongue was stuck and thickly obstinate. He forced a cough to break the tension but a gurgling wet sob escaped him. 'Damn it, hold it together mate! Not today, not now' he railed inside. It didn't matter to Len that he walked with two sticks and had a hip replacement. If he could stand he could walk, there were plenty of other days in the year to sit, but not today, not for them.

The simple truth was, Len got confused. Age and ailment got the better of him. He went to the wrong marshal and by the time he got to his correct spot he was too late. Not being on time cut him deeply. They'd left him behind.

Len cried.

A young army serviceman, his green kit free of rank and medals, found the old digger struggling and gently guided him away from the crowd. The young man sought out a gap by the wall to give the veteran some privacy and a chance to catch his breath. Len blotted his eyes with his handkerchief and heard the young soldier quietly mention something about it being a tough day and a big crowd. At that point bagpipes struck up a sharp howl. A child covered in medals 
skipped past Len and fell into step with other grandchildren, nephews and nieces taking the place of family who could no longer march.

Len thrust out his sticks for the young man to hold. He then straightened his jacket, aligned his medals and just for a small private unassisted moment, stood to attention.

Taking back the sticks both young and old soldier moved in the direction of the pub around the corner. Len muttered to his companion that he just didn't want his old boys to see him like that. The younger soldier commended him, 'Sir, I think your old boys would be proud. I know the young boys are.'

'Well, if you're up for it' requested Len, 'would you mind taking me to The Royal?' 